\title{
CAN SENTIMENT TOWARDS ADVERTISING EXPLAIN MATERIALISM AND VANITY IN THE GLOBALIZATION ERA? EVIDENCE FROM DUBAI
}

\author{
Tarek Mady (Ph.D., Old Dominion University)* \\ Associate Professor of Marketing \\ School of Business Administration \\ The American University in Dubai \\ P.O. Box 28282 \\ Dubai, U.A.E. \\ Phone: +971 43183307 \\ Fax: +971 43998899 \\ Email: tmady@aud.edu
}

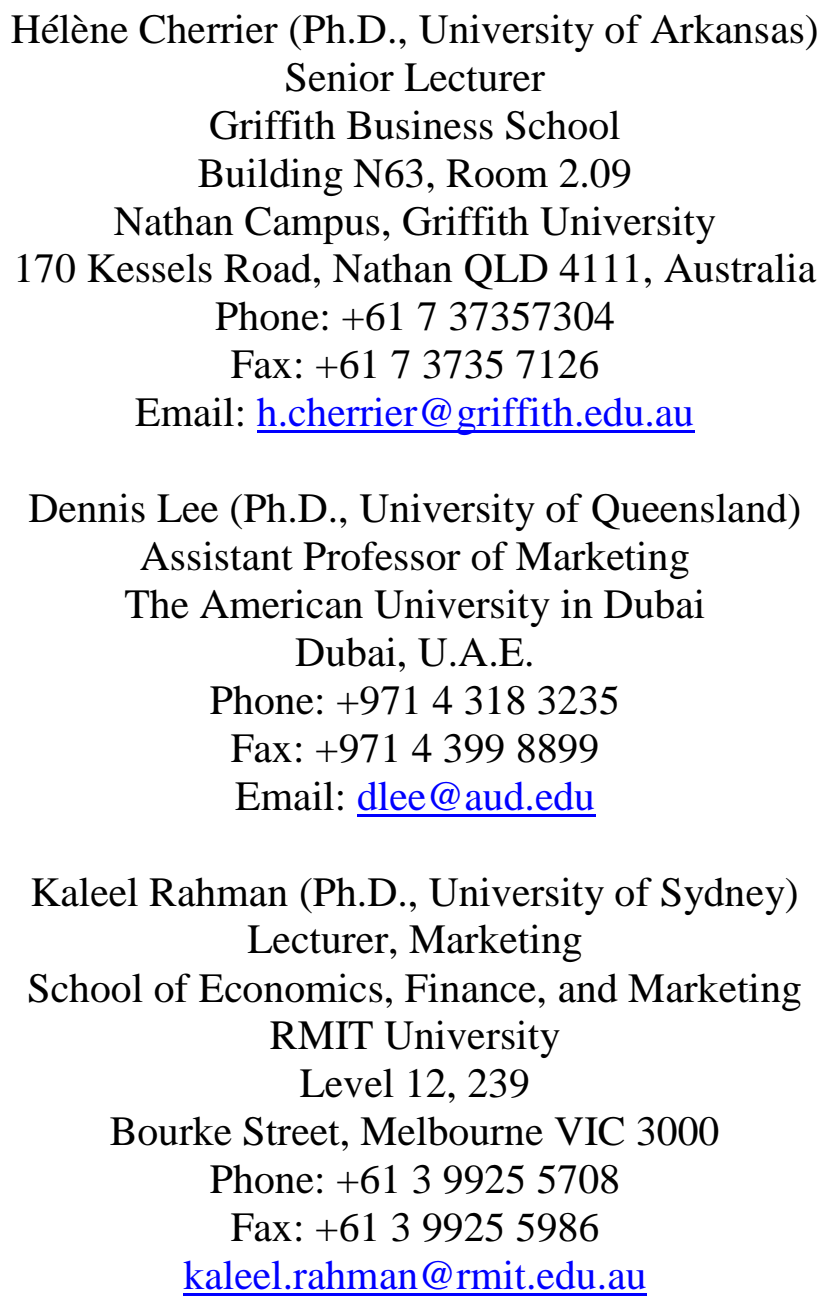

*Please send all correspondences to the first author.

The authors would like to thank the American University in Dubai School of Business Administration for funding of this study as part of the school's Faculty Student Mentorship Grant program. Accordingly, we thank Ms. Ghinna Ahmad, Ms. Marina Anic, Ms. Marisha Gandhi, Ms. Pooja Dhiman, Mr. Hamza Badiuzzaman, and Ms. Aziza Osman for their participation in the fieldwork and data entry processes. 


\title{
CAN SENTIMENT TOWARDS ADVERTISING EXPLAIN MATERIALISM AND VANITY IN THE GLOBALIZATION ERA? EVIDENCE FROM DUBAI
}

\begin{abstract}
This paper presents the first study to address sentiment towards advertising, materialism and vanity in the globalized city of Dubai. A conceptual model is developed and subsequent hypotheses is tested via structural educational modeling (SEM). The main research findings suggest that consumers in Dubai exhibit positive perceptions of advertising as well as higher levels of materialism and vanity. Sentiment toward advertising is found to positively influence materialism levels while materialism strongly influences views, concern for physical appearance, and personal achievement. Sentiment towards advertising, however, has no direct effect on any vanity trait, suggesting that vanity is more an internal personal trait.
\end{abstract}

Keywords: Dubai, sentiment towards advertising, vanity, materialism, global consumer culture, structural equation modeling

The authors would like to thank two anonymous JGM reviewers for their insightful comments and suggestions for improving the quality of the manuscript during the revision process. 


\section{INTRODUCTION}

Ever since Levitt's seminal 1983 paper on the globalization of markets, many researchers have asserted that increasing globalization has led to the emergence of a homogeneous and borderless consumer culture, more accepting of consumerism (e.g., Askegaard, Arnould, \& Kjeldgaard, 2005; Bauman, 1998; Hannerz, 1990; McLuhan \& Powers, 1989; Terpstra \& David, 1991). Mass media originating primarily in the West, including advertising, are perceived to have a major role in the creation, learning, and sharing of these so-called "global" consumer habits (Alden, Steenkamp, \& Batra, 1999; Appadurai, 1990; Walker, 1990;). Criticism of advertising, however, has been extensive and can be subsumed within studies of counter-cultural movements, consumer resistance, antimarketing, anti-consumption, boycotting, or anti-globalization sentiment (Rumbo, 2002). These various studies show advertising to be one of the most powerful media to "manipulate" consumers (Lasch, 1978; 1984). The genius of manipulative advertising, as it is claimed, relies on creating a false consciousness and praising self-expression through materialism (Abela, 2006) and vanity (Durvasula \& Lysonski, 2008), both of which are hallmarks of the globalization age (Durvasula, Lysonski, \& Watson, 2001). In essence, the global consumer culture is characterized by globalized needs, an increased focus on seeking individual selfworth through material symbols, and conformity to a market-mediated material world continuously communicating homogenized images of the "good" life (Clammer, 1997). Consequently, it is argued that global consumers should be more accepting of advertising and have favorable perceptions of its role in communicating the material world (Paek \& Zhongdang, 2004)

A thorough review of the literature, however, indicates that despite a number of country-specific studies addressing general attitudes towards advertising (e.g., Petrovici \& Marinov, 2007; Petrovici \& Paliwoda, 2007; Wills \& Ryan, 1982), few studies shed light on 
consumer sentiment towards advertising within the more relevant and recent context of globalization. Indeed, as consumers increasingly identify with globalization, via a shared consumer culture, personal traits such as materialism and vanity are likely to become more salient (Durvasula, Lysonski, \& Watson, 2001). Yet very little research provides evidence that this is the case. Moreover, with the exception of various theoretical arguments, few researchers empirically demonstrate whether causal relationships between consumer perceptions of advertising and materialism and vanity levels do actually hold in a global perspective.

Studying perceptions of advertising and levels of materialistic values and vanity in socalled "global" cities like Dubai is important, as it involves a context where Western values are often an implied side-effect of increased globalization and openness. As the world becomes more commercially integrated, investigating the power of advertising in global cities and global segments and its impact on materialism and vanity is a prerequisite to understanding the development (or demise) of a global consumer culture, a culture growing in importance and relevance to marketers worldwide.

In the research reported here, we question whether the development of what Guy Debord (1995) calls the "society of the spectacle" is related to the development of increasing materialism and vanity. We ask two specific questions: (1) Do global consumers living in Dubai exhibit more positive perceptions of advertising, as well as higher materialism and vanity levels? (2) If so, are these inflated materialism and vanity-related tendencies influenced by preconceived positive perceptions of advertising? By addressing these two questions we hope to shed light on a budding global consumer culture and offer both academics and practitioners suggestions for communicating with this often misunderstood segment. Figure 1 illustrates the proposed conceptual model based on the aggregate relationships between the constructs. 


\section{Place Figure 1 about here}

We begin with a brief discussion of the study's context, including a description of the global consumer culture in Dubai. In the second section of the paper we discuss the relevant literature pertaining to the main constructs as well as the theoretical underpinnings of the framework and specific hypotheses to be tested. The study's methodology and research design are presented in the third section. We conclude with discussions of the findings and conclusions, managerial implications, limitations, and directions for future research.

\section{CONTEXT: THE CASE OF DUBAI}

\section{A Culture of Excessive Consumerism}

Investigating perceptions of advertising and subsequent materialism and vanity levels within the context of a global city such as Dubai is pertinent considering the rate at which such emerging markets are forming and opening up to global corporate powers and international brands. Dubai is a city born of the globalization era, where the current leadership's desires for modernity and openness have resulted in an implied embracing of more Western values, values traditionally associated with both materialism and vanity. The resulting environment has often been described as a culture of excessive consumerism and marketing. In fact, the first sign travelers to the emirate see at the Dubai Airport proclaims "Welcome to Dubai, Where Shopping is the National Pastime." The current consumer culture is fueled, in part, by a tremendous amount of advertising targeting expatriates and locals alike. Advertising expenditure has grown exponentially in recent years in Dubai (Marks, 2006) and it is this amount of advertising and media propaganda that has somewhat forced consumers into unrealistic levels of consumer spending (Reuters, 2008).

Almost all the major multinational companies have a presence in Dubai. Global products are sold in enormous shopping malls, including the world's largest (The Dubai Mall). Recent economic prosperity, cultural differences, as well as the extremely hot and 
humid weather, have resulted in embracing of the "mall" culture (El-Adly, 2007) and a constant focus on consumption. Furthermore, the Dubai government has been successful in infusing materialistic values into the day-to-day lives of residents and tourists alike, with holiday-like festivals designed to get consumers to spend more. For example, every winter sees the month-long Dubai Shopping Festival (DSF). During this event, the entire city is alight with offers and initiatives designed to entice residents and visiting tourists with the latest and newest products and services. During the particularly harsh summer months, when most expatriates leave for their annual vacations, the ten-week shopping extravaganza known as Dubai Summer Surprises (DSS) occurs. Again, the focus is on consumer spending. By some accounts, families spend up to 60 percent of their income (Haider, 2008) and retailing contributes 50 percent of GDP (Davis, 2006). Whether it is in the city's best interest that consumers continue to indulge themselves with material spending remains unclear, given that the majority of consumer goods in the city are imported. It is interesting, however, that these spending levels have not changed much despite the current economic concerns plaguing the global economy and ongoing worries regarding Dubai's economic stability (Walid, 2010).

One issue is clear: Dubai has positioned itself as a home for luxury brands (Balakrishnan, 2008). Western practices such as cosmetic surgery and beauty therapy, along with boutiques and exclusive department stores carrying the latest and most exclusive beautyenhancing products such as shoes, purses, watches, jewelry, sunglasses, perfume and makeup, disproportionately outweigh shops carrying groceries and convenience goods. Buildings and fences along the main roads and freeways are replete with gigantic advertising billboards displaying Western style models that represent attractiveness, sex appeal, and success - the core of vanity. In fact, a number of reports have noted that this consumer culture glorifying vanity and materialistic lifestyles has led to a "hidden poverty," where a certain segment of the society seeks to possess luxurious items at the expense of essential goods (Reuters, 2008). 


\section{A Global Consumer Culture}

Dubai also offers unique insights in that the city exhibits all the characteristics of a global consumer culture (Cherrier, Mady, \& Mady, forthcoming). The global consumer culture (GCC) is broadly viewed as a cultural entity not associated with a single country, but rather a larger group which is more international and transcending of individual national culture (Alden et al., 1999). Cleveland and Laroche (2007) identify six main drivers to the incorporation of the global consumer culture: (1) cosmopolitanism, (2) exposure to marketing activities of multinational or global corporations, (3) exposure to/use of the English language, (4) global/foreign mass media exposure, (5) openness to and desire to emulate global consumer culture, and (6) social interaction (including travel, migration, and contacts with foreigners). This perspective entails that individuals living in a global city should embrace and endorse a global consumer culture that is more related to global symbols, product categories, brands, and consumption activities.

In fact, a closer look reveals that Cleveland and Laroche's drivers are fundamental to the Dubai culture. First, Dubai is home to more than 1.7 million residents (Dubai Statistics Center, 2010). These residents come from diverse parts of the world to mingle and work together within a multicultural and cosmopolitan environment characterized by global brands and similar consumption habits. Second, Dubai's economic system, with its emphasis on the free flow of products, investments and people, has attracted thousands of international companies in areas such as consumer goods, technology, banking, fashion, construction, and media. Exposure and deference to global corporate influences inscribe Dubai as a "global city" where consumption patterns are often governed by multinational corporations (Balakrishnan, 2008) rather than local firms. Third, while the official language in Dubai is Arabic, most residents speak and interact in English. The English language acts as the common denominator for communication between the different cultures and nationality 
groups in the city and is essential for day-to-day operations including individual consumption activities. Fourth, Dubai hosts an astonishing $90 \%$ of non-nationals from all over the world (Dubai Statistics Center, 2010). Due to such multiculturalism, consumers are constantly exposed to other consumers, marketers, and products that are no longer representative of one nation, one ethnicity, or one cultural domain.

Finally, Dubai is of particular interest to the context of this study because of its nondominant and non-dominating home/host cultural fusion. Although Dubai is multicultural in nature, it cannot be characterized as a "melting pot" situation often evident in other countries where incoming minority migrants acculturate to the dominant (majority) culture (e.g., the U.S., Canada, the U.K.). Expatriates in Dubai have short-term residencies in mind and plan to be in the city for a limited period. As such, there is no tendency to consciously conform to local customs and/or lose touch with one's primary culture. In essence, Dubai is more of a "tossed salad" rather than a melting pot. The culture that prevails or dominates in Dubai is not the Emirati culture, nor the Arab or Asian culture, but the global consumer culture where preference is given to brands with global symbols and meanings (Cherrier et al., forthcoming; Zhou, Teng, \& Poon, 2008).

\section{LITERATURE REVIEW}

\section{Sentiment towards Advertising}

Attitudes toward advertising have been extensively researched (O'Donohoe, 1995). The majority of previous research suggests that consumer purchasing behavior is affected by general attitudes towards the advertising function (Bush, Smith, \& Martin, 1999). For example, many studies have investigated the impact of attitude towards advertising on its effectiveness (e.g., Greyser \& Reece, 1971), attitude towards the specific advertisement (e.g., Bauer \& Greyser, 1968), and attitude towards the brand (e.g., Lutz, 1985; Mackenzie \& Lutz, 1989; Muehling, 1987; Shimp, 1981). The observation has been made that consumers' 
general attitudes towards advertising affect their attitudes toward individual advertisements (Lutz, 1985). Specifically, people with more favorable feelings about advertising in general find specific advertisements more acceptable, informative, and enjoyable (Bauer \& Greyser, 1968). However, research tends to suggest that attitudes toward advertising are only moderately related to demographic factors such as age, gender, income, and education. For example, Durand and Lambert (1985) found that criticisms of advertising were explained more by a sense of consumer and political alienation than by demographic characteristics. They found that the more alienated customers felt, the more advertising was criticized.

Other studies investigating attitudes toward the institution of advertising have often focused on consumers' perceptions of the various aspects of advertising, such as its informational value and its use of idealized images (e.g., Andrews, Durvasula, \& Netemeyer, 1994; Calfee \& Ringold, 1994; Ford \& Calfee, 1986; Muehling, 1987; Pollay \& Mittal, 1993). When advertisement is viewed as a source of information, the literature suggests that sentiment towards it has become more negative over recent years. In studies conducted by Barksdale and colleagues between the 1970s and early 1980s in the U.S. (e.g., Barksdale \& Darden, 1972; Barksdale, Hiram, Darden, \& Perreault, 1976; Barksdale, Perreault, Arndt, Barnhill, French, Halliday, \& Zif, 1982), a clear majority of respondents did not believe advertisements were reliable sources of information about the quality and performance of the advertised products.

Recent international studies have provided similar results. For example, Chan, Yau, and Chan (1990) found that Australian consumers had unfavorable attitudes toward marketing in general and advertising specifically, but asserted that this might be due to cultural values. They argued that consumers from individualistic cultures such as the U.S. and Australia tend to be more dissatisfied with the market environment, whereas consumers living in a collectivistic environment such as Hong Kong place greater emphasis on harmony 
and relationships, and thus tend to be less critical of marketing and the promotion function. More recently, however, Gaski and Etzel (2005) found some improvement in consumer perception towards marketing practices and the advertising function in the U.S..

\section{Materialism}

Materialism has long been studied in the field of marketing. Belk (1985, p. 266) defined materialism as "the importance a consumer attaches to worldly possessions" and measured the concept using subsets of certain personality traits including possessiveness, non-generosity, and envy. Richins and Dawson (1992, p. 307) later delineated materialism as "a mind-set or constellation of attitudes regarding the relative importance of acquisition and possession of objects in one's life". As a value, materialism allows for a segmentation criterion where portions of the population can be classified as materialistic and others as nonmaterialistic (Richins \& Rudmin, 1994). Despite lengthy controversy surrounding the definition and measurement of the construct, recent studies recognize that the conceptualization of materialism as a personal value has achieved broad acceptance (Lerman \& Maxwell, 2006).

Burroughs and Rindfleisch (2002), emphasizing differences between self-centered consumers and collective-oriented consumers, found materialism to be a salient personal trait within individualistic cultures. Similarly, Lerman and Maxwell (2006) used materialism to differentiate between American and Russian consumers as well as Jewish and Christian consumers. Although differences in materialism levels were attributed to culture and/or religious beliefs, Ger and Belk (1996) argued that materialism was neither unique to the West nor directly related to individual affluence. For example, Rose and DeJesus (2007) found that personality traits associated with a strong need to belong predisposed consumers towards being materialistic. Similarly, Mick (1996) noted that highly materialistic individuals were preoccupied with others' opinions. 
It is worth noting, however, that regardless of the particular aspect addressed in these previous studies, each embraces materialism as an intrinsic and natural personal value. When viewed in the literature as inherent to individuals, materialism is found to predict consumers' responses to marketing strategies. For example, highly materialistic consumers react more positively to the symbolic meaning, the quality, and the emotional appeal of the brand, and their purchases are highly influenced by opinion leadership and social motivation (Fitzmaurice \& Comegys, 2006; Sangkhawasi \& Johri, 2007). Highly materialistic consumers tend to shop for longer periods of time and spend more on each purchase than less materialistic individuals (Fitzmaurice \& Comegys, 2006). However, materialistic consumers also tend to express more guilt and feelings of irresponsibility after a splurge purchase than less materialistic individuals (Fitzmaurice, 2008).

On the other hand, several researchers consider materialistic values to be learned rather than intrinsic in nature. That is, materialism is not inherent to individuals but is incorporated or rejected through consumer socialization processes. Under this perspective, consumers are considered malleable by their environment. For example, Roberts, Manolis, and Tanner (2006) showed that family structure had a strong impact on consumer materialism (Rakow, 1992; Roberts et al., 2003). Specifically, they found that experiencing a parental divorce during childhood influenced a person's future level of materialism. Further research on materialism has shown the impact of marketing strategies on material values (e.g., Sangkhawasi \& Johri, 2007).

Vanity

As a value-orientation, vanity refers to a person's concern with and perception of social achievement and physical appearance (Durvasula, Lysonski, \& Watson, 2001). Netemeyer, Burton, and Lichtenstein (1995) developed a psychometrically sound instrument to measure vanity. Their instrument includes two distinct aspects, physical appearance and 
achievement, and each aspect in turn includes two dimensions. Physical appearance includes (a) a concern for physical appearance (e.g., "It is important that I always look good") and (b) a positive (and perhaps inflated) view of physical appearance (e.g., "I am a very goodlooking individual"). The physical appearance aspect of vanity is based on the premise that outward physical appearance is important for establishing and maintaining one's self concept. The proliferation of and willingness to buy appearance-related products and services such as cosmetics, cosmetic surgery, and clothing indicate the kinds of concern consumers have in terms of physical appearance (Solomon, 2006). Concern for physical appearance may have positive implications for consumer behavior (e.g., demand for healthy foods) as well as negative implications (e.g., addictive behaviors) (Bloch \& Richins, 1992). The achievement aspect of vanity includes (a) a concern for achievement (e.g., "I want my achievements to be recognized by others") and (b) a positive, and perhaps inflated, view of achievement (e.g., "I am a good example of professional success"). Achievement-based vanity can be observed when consumers use consumption as a way of demonstrating status and success. As Netemeyer et al. (1995) argued, consumers demonstrate their drive for personal achievement through conspicuous consumption. This is in line with Schiffman and Kanuk's (2006) finding that "achievement and success" rank as core values in American society and subsequently act as justification for the acquisition of goods. Burton, Netemeyer, and Lichtenstein (1995) found that female concerns about physical appearance were greater than male concerns and female perceptions of personal physical appearance were less positive than male perceptions. Recently, Durvasula and Lysonski (2008) found that whereas both men and women were equally concerned with physical appearance and professional achievements, self-assessed views of physical appearance and professional achievements were significantly lower among women than among men. 
The work of Netemeyer et al. (1995) has led several researchers to investigate vanity within an international context. For example, using data from China, India, New Zealand, and the U.S., Durvasula et al. (2001) established the cross-cultural applicability of the vanity scale. Their results showed that the factor structure of the vanity scale was similar across the countries and the scale could be applied in both Western and Eastern cultures. They did, however, find significant differences, with Americans, Chinese, and New Zealanders exhibiting higher concerns for physical appearance. More recently, Wang and Waller (2006) found that female concerns with physical appearance were greater than those of males in both the U.S. and China.

A closer look at the literature reveals that vanity is often considered to be a determining factor for personal traits and future consumption habits. For example, Krantz (1987) found that physical appearance was positively related to social benefits such as increased popularity, power and self-esteem. Feingold (1992) found that attractive people were perceived to be more sociable, sexually warm, mentally healthy, intelligent, and socially skilled than unattractive people. Furthermore, Burton et al. (1995) found concern for physical appearance to be positively related to concern for clothing, public body consciousness, and dieting frequency. They found that concern for physical appearance generated demand for healthy foods, weight control, and exercising equipment and programs.

However, missing in these studies are investigations of the various antecedents to vanity. As Durvasula et al. (2001) pointed out, there are two schools of thought regarding vanity. One view is that vanity is a primary biogenic drive and that it is a personality trait influenced by genes and early socialization. On the other hand, according to Mason's (1981) view, vanity is a secondary psychogenic trait like conspicuous consumption, and hence is largely influenced by one's environment, including prevailing social and economic conditions. Although not formally investigated, the influence of advertising on vanity has 
been suggested by several authors (e.g., Cocanougher \& Bruce, 1971; Gerbner, Gross, Morgan, \& Signorielli, 1994; Richins, 1991; Stephens, Hill, \& Hanson, 1994). These suggestions are highlighted in the following sections as part of the hypotheses development.

\section{RESEARCH HYPOTHESES}

The relationship between sentiment towards advertising and materialism has rarely been empirically addressed in the literature. The conceptual argument linking the two is based on the notion that advertising does more than simply communicate symbols to consumers; it also communicates values (Zinkhan, 1994). Pollay (1983), for example, identified 42 values represented in print and broadcast media, with materialism being a major value communicated in most advertisements. As mentioned previously, materialism represents the importance of acquisition and possession of objects in one's life and the idea that more is better. This "value" is often portrayed in advertisements, where consumers are encouraged to "acquire" the new products. After all, a desire for possessions means increased sales for firms, which is the ultimate goal of most advertising campaigns. It is advertising's glamorized illustration of the good life through material possessions that serves as a primary drive for materialistic consumer behavior (Zinkhan \& Prenshaw, 1994). This is in line with previous research that suggests that materialism is a learned value. Furthermore, and as Bauer and Greyser (1968) noted, individuals with more favorable perceptions of advertising in general tend to accept the information provided in such advertisements, including the values being communicated. As such, it can be argued that there exists a direct positive relationship between consumers' preconceived perceptions of advertising and materialism levels:

$\mathrm{H}_{1}$ : A positive sentiment towards advertising leads to a higher level of materialism.

An extensive body of research suggests that people engage in consumption activities designed specifically to indicate to others that they are successful (e.g., Belk, 1985; Mason, 
1981; Richins \& Dawson, 1992). The research also suggests that an object of materialism takes on the quality of possession or ownership (Belk, 1985; Richins, 1994). In fact, Netemeyer et al. (1995) found a direct positive relationship between materialism and vanity. Richins and Dawson (1992) found that materialistic consumers viewed the acquisition and possession of goods as paramount to illustrating symbols of success and personal achievement. Indeed, the argument can be made that materialism is essentially an antecedent to vanity or, at minimum, a means for satisfying various vanity-related tendencies in individuals, including concerns and perceptions of personal appearance and achievement. Therefore, the following are hypothesized:

$\mathrm{H}_{2 \mathrm{a}}$ : A higher level of materialism leads to a greater concern for physical appearance.

$\mathrm{H}_{2 \mathrm{~b}}$ : A higher level of materialism leads to a more positive view of personal physical appearance.

$\mathrm{H}_{2 \mathrm{c}}$ : A higher level of materialism leads to a greater concern for achievement.

$\mathrm{H}_{2 \mathrm{~d}}$ : A higher level of materialism leads to a more positive view of achievement.

Durvasula et al. (2001) rightly emphasized the contention that the "advertising industry positions products on the basis of consumers' desires to make themselves more physically attractive or to show off their achievement to others" (p. 184). According to McCracken's (1986) meaning transfer model, cultural meaning in the social and physical environment is attached to products and services through advertising and the fashion world. The cultural meaning in products and services, in turn, moves to consumers through rituals such as acquisition of goods and services. The development of vanity traits due to advertising might also be explained by cultivation theory (Gerbner et al., 1994), in which consumers' susceptibility and extensive exposure to advertising are viewed as forces gradually shaping worldly views and social reality. In fact, Gerbner and colleagues found that frequent viewers 
were more likely than infrequent viewers to see their world as it is shown in advertising. Also, according to body dissatisfaction literature (Stephens, Hill, \& Hanson, 1994), models, who are generally portrayed as attractive and successful in advertising, are considered by many to be an aspirational reference group (Cocanougher \& Bruce, 1971). In many cases, these models are the standards by which individuals judge the attractiveness of other ordinary people (Richins, 1991). Martin and Gentry (1997) performed a content analysis of advertising and found that $25 \%$ of advertisements conveyed some form of physical attractiveness message. Hence, positive sentiment towards advertising can lead to an increased level of concern with and view of personal physical appearance, as well as an increased level of concern with and view of personal achievement. The following are hypothesized:

$\mathrm{H}_{3 \mathrm{a}}$ : A positive sentiment towards advertising leads to a greater concern for personal physical appearance.

$\mathrm{H}_{3 \mathrm{~b}}$ : A positive sentiment towards advertising leads to a more positive view of personal physical appearance.

$\mathrm{H}_{3 \mathrm{c}}$ : A positive sentiment towards advertising leads to a greater concern for achievement.

$\mathrm{H}_{3 \mathrm{~d}}$ : A positive sentiment towards advertising leads to a more positive view of achievement.

\section{METHODOLOGY}

\section{Measures and Survey Design}

A number of well-established scales pertaining to the three major constructs of this study exist and extensive research suggests broad cross-cultural validity of these scales. However, best practices in international marketing research suggest the need for a contextual examination of the fit between latent constructs and the appropriateness of the measurement items employed to operationalize them within any culture (Malhotra, Agarwal, \& Peterson, 1996). Specifically, using scales developed within a Western context may or may not reflect the explanatory value to truly reflect the Dubai and global context of our study. To 
accommodate this so-called etic-emic dilemma and establish a level of measurement equivalency, a two step-process was conducted to define the etic (outside looking in) constructs of sentiment towards advertising, materialism, and vanity via established scales, while operationalizing these constructs emically (inside looking out) via qualitative research (e.g., focus groups, in-depth interviews). This combination of etic constructs and emic indicators should result in a scale with improved reliability and validity in different cultures (Malhotra et al., 1996).

As one of the main purposes of the study was to measure consumer sentiment towards advertising, early consideration was given to the index of sentiment towards marketing developed by Gaski and Etzel (1986). The index is designed to measure composite opinions regarding the field and provides a continuing "barometer of how marketing is doing in the eyes of the consumer public" (Gaski \& Etzel, 1986, p. 72). The 20-item scale corresponds to the four elements of the marketing mix: (1) product/quality; (2) price of the product; (3) advertising; and (4) retailing or selling. Gaski and Etzel's index remains the most accepted approach to measuring consumer sentiment towards the marketing function and, more importantly, has been used within an international context (e.g., Chan et al. 1990; Lysonski, Durvasula, \& Watson, 2003). Given the nature of our study, early manifestations of our scale considered Sentiment towards Advertising as measured by the index's five-item sub-scale designed to capture how consumers generally viewed advertising activities in the marketplace. Materialism was considered to be based on the six-item scale developed by Richins (1987). Previous analyses of that scale revealed that materialism is based on two distinct dimensions: personal materialism (four-item scale) and general materialism (twoitem scale). As discussed shortly, these sub-dimensions were not found to be salient in Dubai. Finally, Vanity was measured by the scale developed by Netemeyer et al. (1995). As delineated and operationalized by these authors, "vanity" consists of four distinct trait 
aspects: (a) an excessive concern for physical appearance (five-item scale), (b) a positive (often inflated) view of one's personal physical appearance (six-item scale), (c) an excessive concern for personal achievements (five-item scale), and (d) a positive (often excessive) view of one's personal achievements (five-item scale).

Given the etic manifestations mentioned above, a series of focus groups were conducted using ten MBA students from a private university in Dubai. Recent research indicates that MBA student samples provide acceptable proxies for real consumers, especially with regard to assessing psychological states (e.g., James \& Sonner, 2001). Although a number of scholars suggest that individuals may often be hesitant in discussing their feelings in a group setting, we found no such hesitation. Nonetheless, one-on-one in-depth interviews in private settings with 15 different MBA students were also conducted. In both formats, students were asked to reflect on their salient beliefs of what the three relevant constructs entailed. Minimal input regarding the makeup of the constructs was provided. This method of standard belief elicitation is commonly used in attitude research for generating a list of belief statements (Ajzen \& Fishbein, 1980).

The resulting statements were compared to the established scales under consideration. With the exception of minor wording issues, no significant differences were found with regard to sentiment towards advertising and materialism. Only issues pertaining to sexuality and use of the word "sex" were found to be problematic in the case of vanity. This was expected, given the more conservative nature of the region, and necessary changes were made to the relevant statements. Nevertheless, the relative congruency of the established scales and our findings from the qualitative research verified functional equivalence. The final three constructs and scale items were measured on a 7-point Likert-type scale ranging from strongly agree to strongly disagree.

\section{Questionnaire Administration}


The study was funded in part by a small grant from a private university in Dubai. Surveys were administered via a typical mall-intercept process. In an effort to preempt potential respondent unwillingness to participate, all potential respondents approached were offered a small monetary incentive in the form of a gift card at a mall retailer. Respondents' willingness to participate was noticeably positive. Questionnaires were administered in person. Therefore, response rates and non-response bias could not be assessed. Respondents were not told the purpose of the study but a brief introduction was given about confidentiality matters and scoring anchors. The initial sample was comprised of 387 mall patrons. Prior to carrying out the data analysis, an inspection of the responses was conducted and of the 387 responses obtained, 22 questionnaires were discarded because of excessive missing data. Therefore, the final sample was based on 365 responses and was deemed relatively representative of the Dubai consumer population. Sample characteristics are provided in Table 1.

\section{Place Table 1 about here}

\section{Examination of Construct Validity and Reliability}

Assessing the reliability and validity of the various multi-item scales was based on the guidelines of Churchill (1979) and Gerbing and Anderson (1988). Initial assessments of the three main scales via exploratory factor analyses (EFA) were conducted using a systematic procedure. First, in deciding which items to poll for inclusion in a particular factor model, consideration was given to items that were expected a priori to share common variance. Bartlett's Test of Sphericity and the Kaiser-Meyer-Olkin (KMO) measure of sampling adequacy were inspected for each factor analysis to determine whether items shared a common core. For each analysis, it was possible to reject the Bartlett hypothesis and obtain acceptable KMO values (ranging from .658 to .899). Second, factor loadings for each solution were inspected by examining varimax-rotated pattern matrices. As suggested by 
Hair, Black, Babin, Anderson, and Tatham (2006), a cutoff value of .30 was adopted for deciding which variables to retain for further analysis. Items that did not exhibit significant loadings or exhibited cross-loading were considered for deletion. Third, item-to-total correlations were computed for each relevant construct. Based on the recommendations of Peterson (1994), items that exhibited item-to-total correlations of less than 0.6 were considered for deletion. Finally, Cronbach's alpha values for the each scale were computed and reviewed to determine internal consistency. Only one item was found to be problematic and did not meet these criteria (SentAd5). Throughout the process, items considered for deletion were inspected to ensure that the original meanings of the construct remained unchanged. The various steps were repeated until the factor solutions for each group of items appeared clean and the scales exhibited acceptable levels of reliability and internal consistency. It is worth noting that interpretable factor loadings were not found beyond a onefactor solution for the materialism scale. This is not consistent with the theoretical arguments noted by Richins (1987) that the construct is broken down into personal and general materialism.

Based on the recommendations of Gerbing and Anderson (1988), construct items were then subjected to the more rigorous confirmatory factor analysis (CFA). All indicator loadings on the relevant latent construct were significant and modification indices were low. Only one item was removed due to poor fit properties (ViewPhApp6) and the relevant model was respecified. Several statistics were used to evaluate goodness-of-fit for each factor model including the adjusted chi-square test ( $\chi^{2} /$ degrees of freedom), comparative fit index (CFI), and root mean squared error of approximation (RMSEA). As per the criteria noted by $\mathrm{Hu}$ and Bentler (1999) and Hair et al. (2006), all goodness measures indicated acceptable levels of model fit for each construct. Final scale items, factor loadings, Cronbach alphas, and summary statistics from the CFA analyses are provided in Table 2. 


\section{Place Table 2 about here}

\section{RESULTS}

A series of t-tests and ANOVA analyses were conducted to test for differences regarding sentiment towards advertising, materialism, and vanity based on nationality and years residing in Dubai. Interestingly, no significant differences were found based on either demographic component. This would imply the existence of a homogeneous or "global" consumer culture, at least in regard to the constructs of the model. This is consistent with previous research on the global consumer culture in Dubai (Cherrier et al., forthcoming). To determine whether residents of Dubai exhibited above average levels of sentiment towards advertising, materialism, and vanity, a one-sample $t$-test was conducted. As all scores were measured on a 1 to 7 continuum, the mid-point (neutral point) was identified as four. Table 3 illustrates the results of the one-sample t-test.

\section{Place Table 3 about here}

As indicated in Table 3, residents in Dubai exhibited significantly positive perceptions of advertising as well as above average levels of materialism and all four vanity dimensions. Although not explicitly hypothesized, these findings suggest that residents of a highly globalized city such as Dubai tend to perceive advertising positively and are more materialistic and vain in their consumption habits and lifestyles. The finding that Dubai consumers actually had positive perception of advertising is in direct contrast to the findings in other international research (e.g., Chan et al., 1990). The results, however, are consistent with previous work within a more global context such as Jiuan, Wirtz, Jung, and Keng's (2001) findings that Singaporean consumers exhibited above average materialism levels.

The conceptual model and respective hypotheses were tested using AMOS structural equation modeling (SEM) software. The expanded path and measurement models are illustrated in Figure 2. As evident from Table 4, overall goodness-of-fit measures (adjusted 
Chi-square, GFI, CFI, NFI, and RMSEA) indicate acceptable levels of model fit and interpretable results.

\begin{tabular}{c}
\hline Place Figure 2 about here \\
\hline Place Table 4 about here \\
\hline
\end{tabular}

A detailed look at Table 4 indicates that there was a strong and positive relationship between sentiment towards advertising and materialism. That is, the more positive an individual's perception of advertising was, the more that individual was materialistic and believed that happiness is achieved through possession of goods and services. As such, $\mathrm{H}_{1}$ was supported. The results also indicate a strong positive relationship between materialism levels and all four trait aspects of vanity. This corroborates the earlier findings of Netemeyer et al. (1995). Specifically, highly materialistic respondents were more likely to be concerned with appearance and had a more positive (or inflated) view of themselves when it came to their physical appearance. Moreover, the more materialistic respondents were, the more they valued achievement and the more positive their views were regarding their personal achievements. Therefore, $\mathrm{H}_{2 \mathrm{a}}, \mathrm{H}_{2 \mathrm{~b}}, \mathrm{H}_{2 \mathrm{c}}, \mathrm{H}_{2 \mathrm{~d}}$ were supported. Finally and somewhat surprisingly, the results indicated no direct relationship between sentiment towards advertising and vanity traits. Despite an indirect effect (via materialism), perceptions of advertising had essentially no impact on vanity in Dubai. $\mathrm{H}_{3 \mathrm{a}}, \mathrm{H}_{3 \mathrm{~b}}, \mathrm{H}_{3 \mathrm{c}}, \mathrm{H}_{3 \mathrm{~d}}$ were not supported.

\section{DISCUSSION}

This study represents an early attempt to shed light on a budding global consumer culture in one of the most "global" cities in the world. A number of specific conclusions can be drawn from the analyses. First, consumers in Dubai exhibit high levels of sentiment towards advertising. Despite previous research suggesting generally negative perceptions of advertising, our research finds that perceptions are generally positive, which would imply an 
embracing of advertising as a source of information for day-to-day consumption decisions in an era of globalization. Our findings also suggest that consumers living in Dubai are very materialistic and exhibit inflated concerns and views of physical appearance and personal achievement. Both results are not surprising in today's global consumer culture and are consistent with previous research (e.g., Durvasula, Lysonski, \& Watson, 2001). Increasing materialism levels have long been considered to be associated with the increasing mobility of individuals and the penetration of mass media, which render consumers more exposed to other cultures and consumption styles (Beckmann et al., 2001). The result has been an increased amount of cosmopolitism or world citizenship (Riefler \& Diamantopoulos, 2008) with material gain as a core value governing consumer behavior. This is not necessarily a bad thing. Previous research suggests that highly materialistic societies tend to be more entrepreneurial than less materialistic societies (Uhlaner, Thurik, \& Hutjes, 2002). That is, there is an implied relationship between materialistic values and economic development. It is therefore not surprising that official government sanctioning of material consumption is a priority in Dubai.

With regard to the relationships between sentiment levels, materialism, and vanity, a number of insights have emerged from testing the conceptual model. First, perceptions of advertising play an important role in shaping individual materialistic values in a global context. This is consistent with previous studies of the power of advertising in manipulating consumers' value systems (Bush, Smith, \& Martin, 1999; Calfee \& Ringold, 1988; Pollay \& Mittal, 1993). In that context it is interesting to note that advertising is a powerful medium through which materialistic values can be learned. Materialism has often been considered as intrinsic to individuals' values (Fitzmaurice \& Comegys, 2006; Sangkhawasi \& Johri, 2007). Our findings, however, suggest that consumers' level of materialism is contingent on their environment. That is, materialism is a socially-constructed concept and can spread globally 
by advertising practices. Within a global consumer culture, where exposure to advertising is considerable (and attitudes towards this form of communication are positive), consumer materialism levels become salient to marketers. Hence, one could rephrase the popular Descartes' aphorism: "I shop therefore I am." To this we add the notion of becoming materialistic and learning material values through repeat exposure to the media, images and meanings created and diffused by the marketplace: "I shop there I become." We affirm that cultural values do change and that the globalization of Western ideals, values and belief through global advertising campaigns has the potential to form materialistic cultures.

This particular finding corroborates Levitt's (1983) arguments that a global consumer culture is becoming inevitable, and questions other perspectives suggesting the demise of a global consumer culture to the benefit of local values (e.g., Arnold, 2004; Hannerz, 1990). Indeed, Levitt (1983) argued that geographic segmentation based on national boundaries is becoming less effective. With increased globalization it is clear that consumers are becoming more accepting of advertising and the core value communicated, namely materialism. Assuming that local cultures are becoming irrelevant, however, is certainly too extreme a view.

Another observation arising from our findings is that advertising does not play a significant role in determining vanity levels. We hypothesized that sentiment toward advertising positively influences each dimension of vanity. Our results failed to support any of the relevant hypotheses. As noted earlier, there are two schools of thought as to what makes consumers vain. On the one hand, vanity is seen as a primary biogenic drive, and as a personality trait influenced by genes and perhaps early socialization. On the other hand, and as suggested by Mason (1981), vanity is a secondary psychogenic trait, and hence is largely influenced by the prevailing social and economic conditions. Concerns like "importance of looking good" and "obsession with professional achievements" are not taught by one's 
environment but are more a function of individual personality. Our results seem to support the first perspective that asserts vanity is more of an innate property guiding consumer behavior.

\section{MANAGERIAL IMPLICATIONS}

The immediate findings of the study suggest that firms targeting "global" segments should rely on advertising as the dominant form of communication because these consumers have positive perceptions of the advertising function and increased sales, via materialism, can be achieved. In essence, advertising is important for the continued globalization of markets. That is, an effective and appropriate advertisement can reach its global audience successfully and the message found in the advertisement can affect individual consumers' behavior, attitudes, and beliefs. This same message will influence individual materialism.

There is evidence from the wider literature that personal values are influenced by media (Samuel et al., 2007; Zinkhan, 1994; Zinkhan \& Prenshaw, 1994). As such, advertisers or marketers might be advised to focus on the relevant importance of what the advertised product can do for consumers when they use it. It is common to see advertisements in Dubai that highlight only the features and characteristics of advertised products. Companies intending to advertise might be advised to consider also outlining the benefits or advantages of possessing their products, given that their consumers are highly materialistic in nature. People in Dubai are known for their flashy and extravagant purchases. Expensive cars, clothing, buildings, and yachts are typical sights in most parts of Dubai. Consumers in the city want quality and expensive products. Understanding such sentiments toward local advertising practices should be able to give marketing companies some insight into how to establish their business practices. Moreover, since it was found that materialism can affect individual vanity levels, the success of the value perception of acquiring a product is likely to be relatively important to consumers not only in Dubai but also in the greater and 
geographically-dispersed global consumer culture. Transnational companies should ensure that both the intrinsic and the physical attributes of their products appeal to the social and personal identity of the individual consumer. That is, companies are reminded to create an advertising message that not only informs but also reinforces the greater need for having the product, the happiness that stems from owning it, and the contributions of this possessive aspect on perception of one's physical appearance and achievement.

One issue worth noting is that the structure of the model tested in this study suggests that sentiment towards advertising is uncontrollable. That may be true to some degree. However, previous research has suggested that marketers can have an indirect impact on sentiment levels. For example, Wilkie and Moore (1999) noted the social responsibilities of advertising, including providing better information and choice to consumers. The ramifications of these societal objectives are understandable. However, it is interesting that the results of this study indicate other positive outcomes, including encouraging consumers to be more materialistic. The reality, however, is that improving overall sentiment level is extremely difficult. Counter-consumer-culture movements are growing and resistance to advertising is certainly a powerful force (Rumbo, 2002). Such forces are not immediately obvious in Dubai but the question remains: How can marketers improve sentiment levels? A closer look at the items used to operationalize sentiment towards advertising suggests that global consumer perceptions of advertising are a function of credibility ("Most advertising makes false claims"), how enjoyable or creative ads are ("I enjoy most ads" and "Most advertising is very annoying”), and general perceptions of advertising's impact on consumer wellbeing ("If most advertising were eliminated, consumers would be better off"). Certainly, improving general attitudes towards advertising can be based on improving perceptions of credibility and overall views that advertising is there to help consumers make better decisions. This could be achieved through combined efforts on the part of advertising 
agencies and regulatory authorities designed to gradually instill a level of trust in the advertising function through efforts to curb false claims and limiting advertising's intrusiveness.

On the other hand, our study's findings also reinforce the necessity of embracing social responsibility in advertising campaigns. Awareness of the connection between global advertising campaigns and level of materialism alerts managers to consider their social responsibility when designing campaigns and diffusing materialistic lifestyles across the globe. Emerging markets are vulnerable to Western appeal and yet, as Western experience has already taught us, materialism does not necessarily brings happiness (Belk, 1985). Furthermore, marketing managers have an increasing responsibility toward the environment. If global advertising campaigns have the potential to create a material culture, what would become of our planet once consumers from emerging countries rightly demand selfindulgence via material consumption? Our study positions social responsibility and sustainability as crucial elements in the design and implementation of any global advertising campaigns. If our proposition reflects truth, we should question the globalization process and its impact on happiness and stress levels (Belk, 1985).

\section{LIMITATIONS AND SUGGESTIONS FOR FUTURE RESEARCH}

The results of this study are promising and suggest relationships between the perception of advertising and materialism and vanity. Nonetheless, our findings are limited on a number of dimensions and provide a basis for future research. First, we measured consumer sentiment towards advertising (which is an attitude) and not advertising per se. For example, our measures included such items as "I enjoy most ads" and "Most advertising is very annoying". If we had measured, for example, the amount of advertising the respondents viewed or the frequency of advertising the respondents encountered, the results might have been slightly different. Incorporating these variables might be a fruitful avenue for further 
research to confirm our findings. Another possible reason for our findings may be a relatively lower level of influence of advertising among other competing environmental factors, extraneous variables that our study failed to include. We conducted our study in Dubai, where consumers are constantly bombarded visually with the some of the largest skyscrapers, the largest hotels, the most expensive cars, stores keeping the most luxurious brands, boutiques for cosmetic surgery, beauty therapies, and spas - all these are part of a consumer environment conveying success, achievement and the importance of appearance. In comparison to this "actual" exposure, encounter and experience in this consumer environment, advertising (which presents these factors in a virtual form) of these appearanceand achievement-enhancing factors may have been relatively insignificant, at least to the respondents in our study. As we did not measure these variables in our study, we might have been unsuccessful in capturing some of the variables making up the respondents' environment.

Replication and testing of the model in different countries is also worthy of future research. The strength of the relationships may be different. A multi-country/culture comparison can be conducted to either support (or refute) the conclusions drawn from this investigation. For example, in this study we found a strong relationship between perceptions of advertising and materialism in a global city. The underlying theme is that consumers in such cities are mature and fully understand advertising and its role in society. However, does that same relationship hold in less-developed segments or areas, where consumers are less mature in their beliefs about what advertising is or does (e.g., Africa)? Does materialism still have an effect on vanity or is vanity a function of cultural background? The contextual nature of the model is certainly worth exploring further in other countries or with consumers not so influenced by globalization. 


\section{REFERENCES}

Abela, A. (2006). Marketing and consumption: A response to O'Shaughnessy and O'Shaughnessy. European Journal of Marketing, 40(1/2), 5-16.

Ajzen, I., \& Fishbein, M. (1980). Understanding attitudes and predicting behavior. Englewood Cliffs, NJ: Prentice Hall.

Alden, D. L., Steenkamp, J. E. M., \& Batra, R. (1999). Brand positioning through advertising in Asia, North America, and Europe: The role of global consumer culture. Journal of Marketing, 63(1), 75-87.

Andrews, J. C., Durvasula, S. \& Netemeyer, R. G. (1994). Testing the cross-national applicability of U.S. and Russian advertising belief and attitude measure. Journal of Advertising, 23(1), 71-83.

Appadurai, A. (1990). Disjuncture and differences in the global economy. In M. Featherstone (Ed.), Global culture, nationalism, globalization and modernity (pp. 295-310). London: Sage.

Arnold, D. J. (2004). The mirage of global markets: How globalizing companies can succeed as markets localize. Upper Saddle River, NJ: Prentice Hall.

Askegaard, S., Arnould, E., \& Kjeldgaard, D. (2005). Postassimilationist ethnic consumer research: Qualifications and extensions. Journal of Consumer Research, 32(1), 16070.

Balakrishnan, M. S. (2008). Dubai - A star in the east: A case study in strategic destination branding. Journal of Place Management and Development, 1(1), 62-91.

Barksdale, H. C., \& Darden, W. R. (1972). Consumer attitudes toward marketing and consumerism. Journal of Marketing, 36(4), 28-35.

Barksdale, H. C., Hiram, C., Darden, W. R., \& Perreault, W. D. Jr. (1976). Changes in consumer attitudes toward marketing, consumerism and government regulations: 1971-1975. The Journal of Consumer Affairs, 10(2), 117-139.

Barksdale, H. C., Perreault, W. D. Jr., Arndt, J., Barnhill, J. A., French, W. A., Halliday, M., \& Zif, J. (1982). A cross national survey of consumer attitudes towards marketing practices, consumerism and government regulations. Columbia Journal of World Business, 17(2), 71-85.

Bauer, R. A., \& Greyser, S. A. (1968). Advertising in America: The consumer view. Boston: Harvard University Press.

Bauman, Z. (1998). Globalization: The human consequences. New York: Columbia University Press.

Beckmann, S., Douglas, S., Botschen, G., Botschen, M., Friese, S., \& Nijssen, E. (2001). The worldminded consumer: A emic exploration. In M. Gilly \& J. Meyers-Levy (Eds.), Advances in consumer research. Vol. 28 (pp.138-144). Provo, UT: Association for Consumer Research.

Belk, R. W. (1985). Materialism: Trait aspects of living in the material world. Journal of Consumer Research, 12(3), 265-280. 
Bloch, P. H., \& Richins, M. L. (1992). You look marvelous: The pursuit of beauty and the marketing concept. Psychology and Marketing, 9(1), 3-15.

Burroughs, J. E., \& Rindfleisch, A. (2002). Materialism and well-being: A conflicting values perspective. Journal of Consumer Research, 29(3), 348-370.

Burton, S., Netemeyer, R. G., Lichtenstein, R. D. (1995). Gender differences for appearancerelated attitudes and behaviors: Implications for consumer welfare. Journal of Public Policy and Marketing, 14(1), 60-75.

Bush, A. J., Smith, R. \& Martin, C. (1999). The influence of consumer socialization variables on attitude toward advertising: A comparison of African-Americans and Caucasians. Journal of Advertising, 28(3), 13-24.

Calfee, J. E., \& Ringold, J. D. (1988). Consumer skepticism and advertising regulation: What do the polls show? In M. J. Houston (Ed.), Advances in Consumer Research, Vol. 15, (pp. 244-248). Provo, UT: Association for Consumer Research.

Calfee, J. E., \& Ringold, J. D. (1994). The 70\% percent majority: Enduring consumer beliefs about advertising. Journal of Public Policy \& Marketing, 13(2), 228-238.

Chan, E., Yau, H. M. O. \& Chan, R. (1990). Consumer sentiment in Australia: A replication and cross-national comparison. European Journal of Marketing, 24(10), 44-58.

Cherrier, H., Mady, T., \& Mady, S. (forthcoming). Global or glocalized consumers? An analysis of consumers living the globalizing city of Dubai. Journal of International Consumer Marketing.

Churchill, G. A. Jr. (1979). A paradigm for developing better measures of marketing constructs. Journal of Marketing Research, 16(1), 64-73.

Clammer, J. (1997). Contemporary urban Japan: A sociology of consumption, Oxford: Blackwell.

Cleveland, M., \& Laroche, M. (2007). Acculturation to the global consumer culture: Scale development and research paradigm. Journal of Business Research, 60, 249-259.

Cocanougher, A. B., \& Grady, D. B. (1971). Socially distant reference groups and consumer aspirations. Journal of Marketing Research, 8(3), 379-383.

Davis, J. (2006). The rental question: Interview with MD of Colliers International, Dubai and Retail ME), Retail ME Annual Edition, 151-152.

Debord, G. (1995). The society of the spectacle. New York: Zone Books.

Dubai Statistics Center (2010). 2009 Labor Force Survey Bulletin. Retrieved from: http://www.dsc. gov.ae

Durand, R. M., \& Lambert, V. Z. (1985). Alienation and criticisms of advertising. Journal of Advertising, 14(3), 9-17.

Durvasula, S., \& Lysonski, S. (2008). A double-edge sword: Understanding vanity across cultures. Journal of Consumer Marketing, 25(4), 230-244.

Durvasula, S., Lysonski, S., \& Watson, J. (2001). Does vanity describe other cultures? A cross-cultural examination of the vanity scale. Journal of Consumer Affairs. 35(1), 180-199. 
El-Adly, M. I. (2007). Shopping malls attractiveness: A segmentation approach. International Journal of Retail \& Distribution Management, 35(11), 936-950.

Feingold, A. (1992). Good looking people are not what we think. Psychological Bulletin. 111(2), 304.341.

Fitzmaurice, J. (2008). Splurge purchases and materialism. Journal of Consumer Marketing, 25(6), 332-338.

Fitzmaurice, J., \& Comegys, C. (2006). Materialism and social consumption. Journal of Marketing Theory and Practice, 14(4), 287-299.

Ford, G. T., \& Calfee, J. E. (1986). Recent developments in FTC policy on deception. Journal of Marketing, 50(3), 82-103.

Gaski, J. F., \& Etzel, M. J. (1986). The index of consumer sentiment towards marketing. Journal of Marketing, 50(3), 71-81.

Gaski, J. F., \& Etzel, M. J. (2005). National aggregate consumer sentiment toward marketing: A thirty-year retrospective and analysis. Journal of Consumer Research, 31(4), 859867.

Gerbing, D. W., \& Anderson, J. C. (1988). An updated paradigm for scale development incorporating unidimensionality and its assessment. Journal of Marketing Research, 25 (May), 186-192.

Gerbner, G., Gross, L., Morgan, M., \& Signorielli, N. (1994). Growing up with television: The cultivation perspective. In J. Bryant \& Z. Dolf (Eds.), Media Effects: Advances in Theory and Research (pp. 17-21). Hillsdale, NJ: Lawrence Erlbaum

Greyser, S. A., \& Reece, B. B. (1971). Businessmen look hard at advertising. Harvard Business Review, 49(May-June), 18-36.

Haider, H. (2008, June 28). UAE tops in daily per capita spending in world. Khaleej Times Online. Retrieved from: http://www.khaleejtimes.com/DisplayArticle.asp?xfile= data/business/2008/June/business_June939.xml\&section=business\&col=

Hair, J. F., Black, W. C., Babin, B., Anderson, R. E., \& Tatham, R. L. (2006), Multivariate data analysis $\left(6^{\text {th }}\right.$ ed.). Upper Saddle River, NJ: Prentice Hall.

Hannerz, U. (1990). Cosmopolitans and locals in a world culture. In M. Featherstone (Ed.), Global culture, nationalism, globalization and modernity (pp. 237-251). London: Sage.

Hu, L. T., \& Bentler, P. M. (1999). Cutoff criteria for fit indexes in covariance structure analysis: Conventional criteria versus new alternatives. Structural Equation Modeling: A Multidisciplinary Journal, 6, 1-55.

James W. L, \& Sonner, B. S. (2001). Just say no to traditional student samples. Journal of Advertising Research, 41(5), 63-71.

Jiuan, T. S., Wirtz, J., Jung, K., \& Keng, K. A. (2001). Singaporeans' attitudes towards work, pecuniary adherence, materialism, feminism, environmental consciousness, and media credibility. Singapore Management Review, 23(1), 59-86.

Krantz, M. (1987). Physical attractiveness and popularity. Psychological Reports, 60, 723 729. 
Lasch, C. (1978). The culture of narcissism: American life in an age of diminishing expectations. New York: Norton.

Lasch, C. (1984). The minimal self: Psychic survival in troubled times. New York: Norton.

Lerman, D., \& Maxwell, S. (2006). Joining a consumer society: Russian immigrant versus American materialism. Journal of Consumer Behavior, 5(6), 479-490.

Lutz, R. J. (1985). Affective and cognitive antecedents of attitude toward the ad: A conceptual framework. In L. Alwitt \& A. A. Mitchell (Eds.), Psychological processes and advertising effects: Theory, research and applications (pp. 45-45). Hillsdale, NJ: Erlbaum.

Lysonski, S., Durvasula, S., \& Watson, J., (2003). Should marketing managers be concerned about attitudes towards marketing in New Zealand? A longitudinal view. European Journal of Marketing, 37(3/4), 386-406.

MacKenzie, S. B., \& Lutz, R. J. (1989). An empirical examination of the structural antecedents of attitude toward the ad in an advertising pretesting context. Journal of Marketing, 53(2), 48-65.

Malhotra, N. K., Agarwal, J., \& Peterson, M. (1996). Methodological issues in cross-cultural marketing research: A state-of-the-art review. International Marketing Review, 13(5), $7-43$.

Marks, J. (2006, October 5). Overview - Dubai creates a template. Foreign Direct Investment. Retrieved from: http://www.fdimagazine.com

Martin, M. C., \& Gentry, J. W. (1997). Stuck in the model trap: The effects of beautiful models in ads on female pre-adolescents and adolescents. Journal of Advertising, 26 (2), 19-33.

Mason, R. S. (1981). Conspicuous consumption. New York: St. Martin's Press.

McCracken, G. (1986). Culture and consumption: A theoretical account of the structure and movement of the cultural meaning of consumer goods. Journal of Consumer Research, 13(1), 71-85.

McLuhan, M., \& Powers, B. R. (1989). The global village: Transformations in world life and media in the 21st century. Oxford: Oxford University Press.

Mick, D. G. (1996). Are studies of dark side variables confounded by socially desirable responding? The case of materialism. Journal of Consumer Research, 23(2), 106-119.

Muehling, D. D. (1987). An investigation of factors underlying attitude towards advertising in general. Journal of Advertising, 16(1), 32-40.

Netemeyer, R., Burton, S., \& Lichtenstein, D. R. (1995). Trait aspects of vanity: Measurement and relevance to consumer behavior. Journal of Consumer Research, 21(4), 612-626.

O'Donohoe, S. (1995). Attitudes to advertising: A review of British and American research. International Journal of Advertising, 14(3), 245-261.

Paek, H.J., \& Zhongdang, P. (2004). Spreading global consumerism: Effects of mass media and advertising on consumerist values in China. Mass Communication and Society, 7(4), 491-515. 
Peterson, R. A. (1994). A meta-analysis of Cronbach's coefficient alpha. Journal of Consumer Research, 21(2), 381-391.

Petrovici, D., \& Marinov, M. (2007). Determinants and antecedents of general attitudes towards advertising: A study of two EU accession countries. European Journal of Marketing, 41(3/4), 307-326.

Petrovici, D., \& Paliwoda, S. (2007). An empirical examination of public attitudes towards advertising in a transitional economy. International Journal of Advertising, 26(2), 247-276.

Pollay, R. W. (1983). Measuring the cultural values manifest in advertising. In J. Leigh, H. Martin \& R. Claude (Eds.), Current issues and research in advertising (pp 71-92). Ann Arbor, MI: University of Michigan Press.

Pollay, R. W., \& Mittal, B. (1993). Here's the beef: Factors, determinants, and segments in consumer criticism of advertising. Journal of Marketing, 57(3), 98-114.

Rakow, L. F. (1992). Women making meaning: New feminist directions in communication. New York: Routledge.

Reuters (2008, June 29). Consumer splurge threatens UAE economy. Retrieved from: http://www.reuters.com/article/idUSL2959468920080629

Richins, M. L. (1987). Media, materialism, and human happiness. In M. Wallendorf \& P. Anderson (Eds.), Advances in Consumer Research, Vol. 11 (pp. 291-297). Provo, UT: Association for Consumer Research.

Richins, M. L. (1991). Social comparison and the idealized images of advertising. Journal of Consumer Research, 18(1), 71-83.

Richins, M. L. (1994). Special possessions and the expression of material values. Journal of Consumer Research, 21(3), 522-533.

Richins, M. L., \& Dawson, S. (1992). A consumer values orientation for materialism and its measurement: Scale development and validation. Journal of Consumer Research, 19(3), 303-315.

Richins, M. L., \& Rudmin, F. W. (1994). Materialism and economic psychology. Journal of Economic Psychology, 15(2), 217-232.

Riefler, P., \& Diamantopoulos, A. (2008). Consumer cosmopolitanism: Review and replication of the CYMYC scale. Journal of Business Research, 62, 407-419.

Roberts, J. A., Manolis, C., \& Tanner, J. F. Jr. (2003). Family structure, materialism, and compulsive buying: A re-inquiry and extension. Journal of the Academy of Marketing Science, 31(3), 300-311.

Roberts, J. A., Manolis, C., \& Tanner, J. F. Jr. (2006). Adolescent autonomy and the impact of family structure on materialism and compulsive buying. Journal of Marketing Theory and Practice, 14(4), 301-314.

Rose, P., \& DeJesus, S. P. (2007). A model of motivated cognition to account for the link between semi-monitoring and materialism. Psychology \& Marketing, 24(2), 93-115.

Rumbo, J. D. (2002). Consumer resistance in a world of advertising clutter: The case of Adbusters. Psychology \& Marketing, 19(2), 127-148. 
Sangkhawasi, T., \& Johri, L. M. (2007). Impact of status brand strategy on materialism in Thailand. Journal of Consumer Marketing, 24(5), 275-282.

Schiffman, L. G., \& Kanuk, L. L. (2006). Consumer behavior (9th ed.). Upper Saddle, NJ: Prentice Hall.

Shimp, T. A. (1981). Attitude toward the ad as a mediator of consumer brand choice. Journal of Advertising. 10(2), 9-15.

Solomon, M. (2006). Consumer behavior. Upper Saddle, NJ: Prentice-Hall.

Stephens, D. L., Hill, R. P., \& Hanson, C. (1994). The beauty myth and female consumers: The controversial role of advertising. Journal of Consumer Affairs. 28(1), 137-153.

Terpstra, V., \& David, K. (1991). The cultural environment of international business (3rd ed.). Cincinnati, $\mathrm{OH}$ : Southwest.

Uhlaner, L. M., Thurik, A. R., \& Hutjes, J. (2002). Post-Materialism as a Cultural Factor Influencing Entrepreneurial Activity Across Nations, ERIM Report Series Ref. ERS2002-62-STR.

Walid, T. (2010, June 5). Dubai keeps Mideast luxury crown despite crisis. Khaleej Times Online. Retrieved from: http://www.khaleejtimes.com/darticlen.asp?xfile= data/business/2010/June/business_June91.xml\&section=business

Walker, C. (1996), Can TV save the planet? American Demographics, 18, 42-49.

Wang, P. Z., \& Waller, D. S. (2006). Measuring consumer vanity: A cross-cultural validation. Psychology and Marketing, 23(8), 665-687.

Wilkie W. L., \& Moore, E. S. (1999). Marketing contributions to society. Journal of Marketing, 63(Special Issue), 198-218.

Wills, J.R., \& Ryans, J.K. (1982). Attitudes toward advertising: A multinational study. Journal of International Business Studies, 13(3), 121-129.

Zhou, L., Teng, L., \& Poon, P. S. (2008). Susceptibility to global consumer culture: A threedimensional scale. Psychology \& Marketing, 25(4), 336-51.

Zinkhan, G. M. (1994). Advertising, materialism, and quality of life. Journal of Advertising, 23(2), 1-4.

Zinkhan, G. M., \& Prenshaw, P. J. (1994). Good life images and brand name associations: Evidence from Asia, America, and Europe. In C. Allen \& J. D. Roedder (Eds.), Advances in Consumer Research, Vol. 21 (pp. 496-500). Provo, UT: Association for Consumer Research. 
FIGURE 1. Conceptual Framework

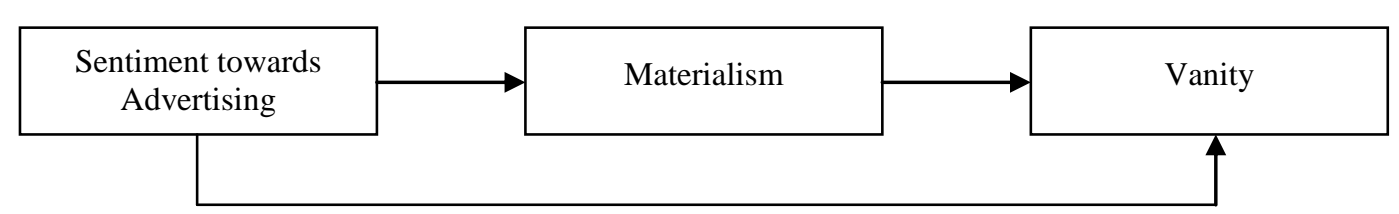


TABLE 1. Demographic Data of Sample

\begin{tabular}{lll}
\hline & & $\mathrm{n}(\%)$ \\
\hline $\mathbf{N}$ & & $\mathbf{3 6 5}$ \\
Age: & Mean & 31.03 \\
& Std. deviation & 9.818 \\
& & \\
& Male & $212(58 \%)$ \\
& Female & $153(42 \%)$ \\
Nationality & \\
& Arab (UAE citizen) & $55(15 \%)$ \\
& Arab (Expatriate) & $121(33 \%)$ \\
& Asian (India, Pakistan, Philippines, etc.) & $152(42 \%)$ \\
& Western (Britain, U.S., Australia, etc.) & $37(10 \%)$ \\
Years in Dubai: & 7.10 \\
& Mean & 7.912 \\
& Std. Deviation & 1 \\
& Minimum & 43 \\
\hline
\end{tabular}


TABLE 2. Scale Items and Summary Statistics

\begin{tabular}{|c|c|c|c|c|}
\hline Variable & Factor/Item & $\begin{array}{c}\text { Factor } \\
\text { Loading } \\
\text { (EFA) }\end{array}$ & $\begin{array}{c}\text { Cronbach } \\
\text { alpha }\end{array}$ & $\begin{array}{c}\text { Summary } \\
\text { Statistics } \\
\text { (CFA) }\end{array}$ \\
\hline \multicolumn{3}{|c|}{ Consumer Sentiment Towards Advertising } & .887 & $\chi^{2} /(\mathrm{df})=1.74$ \\
\hline SentAd1 & Most advertising is very annoying.* & .762 & & $p=.176$ \\
\hline SentAd2 & Most advertising makes false claims.* & .703 & & $\mathrm{CFI}=.99$ \\
\hline SentAd3 & If most advertising were eliminated, consumers would be better off. $*$ & .761 & & RMSEA $=.045$ \\
\hline SentAd4 & I enjoy most ads. & .971 & & \\
\hline SentAd5 & Most advertising is intended to deceive rather than inform. ${ }^{*}$ & - & & \\
\hline \multicolumn{2}{|l|}{ Materialism } & & .690 & $\chi^{2} /(\mathrm{df})=6.29$ \\
\hline Mat1 & It is important for me to have really nice things. & .663 & & $p=.000$ \\
\hline Mat2 & I would like to be rich enough to buy anything I want. & .785 & & $\mathrm{CFI}=.91$ \\
\hline Mat3 & I'd be happier if I could afford to buy more things. & .715 & & RMSEA $=.120$ \\
\hline Mat4 & $\begin{array}{l}\text { It sometimes bothers me quite a bit that I can't afford to buy all the } \\
\text { things I want. }\end{array}$ & .712 & & \\
\hline Mat5 & People place to much emphasis on material things.* & .695 & & \\
\hline Mat6 & It's really true that money can buy happiness & .545 & & \\
\hline \multicolumn{2}{|c|}{ Concern for Physical Appearance } & & .825 & $\chi^{2} /(\mathrm{df})=3.24$ \\
\hline ConPhApp1 & The way I look is extremely important to me. & .789 & & $p=.006$ \\
\hline ConPhApp2 & I am very concerned about my appearance. & .798 & & $\mathrm{CFI}=.99$ \\
\hline ConPhApp3 & $\begin{array}{l}\text { I would feel embarrassed if I was around people and did not look my } \\
\text { best. }\end{array}$ & .694 & & RMSEA $=.078$ \\
\hline ConPhApp4 & Looking my best is worth the effort. & .774 & & \\
\hline ConPhApp5 & It is important that I always look good. & .800 & & \\
\hline \multicolumn{2}{|c|}{ View of Physical Appearance } & & .851 & $\chi^{2} /(\mathrm{df})=2.69$ \\
\hline ViewPhApp1 & People notice how attractive I am. & .688 & & $p=.019$ \\
\hline ViewPhApp2 & My looks are very appealing to others. & .848 & & $\mathrm{CFI}=.99$ \\
\hline ViewPhApp3 & People are envious of my good looks. & .799 & & RMSEA $=.068$ \\
\hline ViewPhApp4 & I am a very good-looking individual. & .811 & & \\
\hline ViewPhApp5 & My body is appealing. & .824 & & \\
\hline ViewPhApp6 & I have the type of body that people want to look at." & - & & \\
\hline \multicolumn{2}{|c|}{ Concern for Achievement } & & .762 & $\chi^{2} /(\mathrm{df})=3.94$ \\
\hline ConAch1 & Profession achievements are an obsession with me. & .754 & & $p=.001$ \\
\hline ConAch2 & I want others to look up to me for my accomplishments. & .778 & & $\mathrm{CFI}=.99$ \\
\hline ConAch3 & $\begin{array}{l}\text { I am more concerned with professional success than most people I } \\
\text { know. }\end{array}$ & .782 & & RMSEA $=.089$ \\
\hline ConAch4 & Achieving greater success than my peers is important to me. & 689 & & \\
\hline ConAch5 & I want my achievement to be recognized by others. & .572 & & \\
\hline \multicolumn{2}{|c|}{ View of Achievement } & & .780 & $\chi^{2} /(\mathrm{df})=3.91$ \\
\hline ViewAch1 & In a professional sense, I am a very successful person. & .724 & & $p=.001$ \\
\hline ViewAch2 & My achievements are highly recognized by others. & .742 & & $\mathrm{CFI}=.99$ \\
\hline ViewAch3 & I am an accomplished person. & .670 & & RMSEA $=.090$ \\
\hline ViewAch4 & I am a good example of professional success. & .794 & & \\
\hline ViewAch5 & Others wish they were as successful as me. & .720 & & \\
\hline
\end{tabular}


TABLE 3. Sentiment towards Advertising, Materialism, and Vanity in Dubai

\begin{tabular}{lrrr}
\hline & $\mathrm{N}=369$ & & \\
\hline Construct & Mean (Std. Dev.) & t-value & $\begin{array}{c}\text { Prob t } \\
\text { Ho: Mean }=4\end{array}$ \\
\hline Sentiment towards Advertising & $4.27(1.57)$ & 3.34 & .001 \\
Materialism & $4.64(1.04)$ & 11.85 & .000 \\
Concern for Physical Appearance & $4.97(1.16)$ & 16.11 & .000 \\
View of Physical Appearance & $4.43(1.13)$ & 7.29 & .000 \\
Concern for Achievement & $4.71(1.12)$ & 12.05 & .000 \\
View of Achievement & $4.90(.96)$ & 18.00 & .000 \\
\hline
\end{tabular}


FIGURE 2. Path and Measurement Model

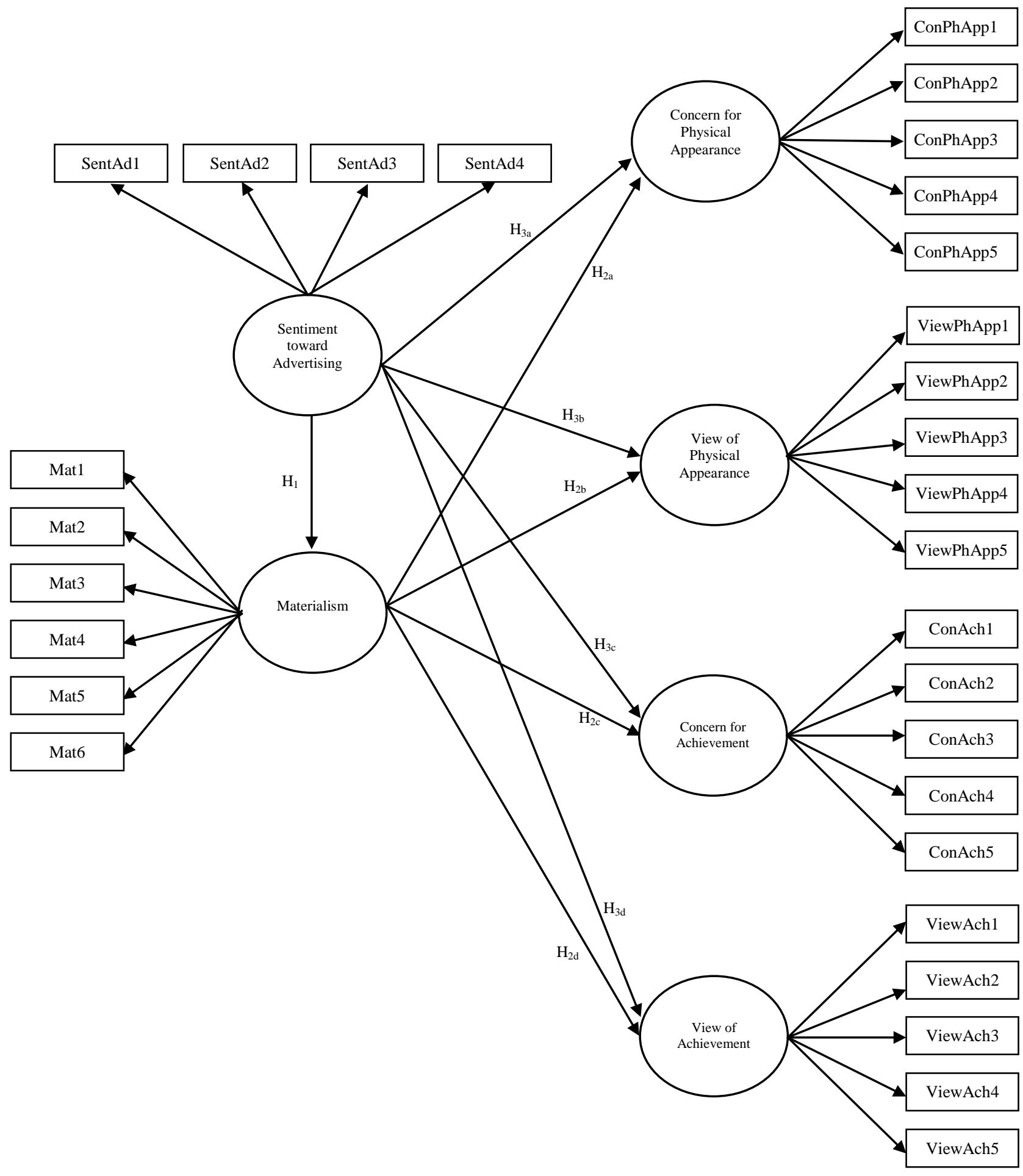


TABLE 4. Path Estimates for Proposed Model

\begin{tabular}{|c|c|c|c|c|}
\hline Hypothesis: Causal Relationship & $\begin{array}{c}\text { Unstandardized } \\
\text { Estimate (St. Error) }\end{array}$ & $\begin{array}{c}\text { Critical } \\
\text { Ratio }\end{array}$ & $\begin{array}{c}\mathrm{P}- \\
\text { Value }\end{array}$ & $\begin{array}{c}\text { Standardized } \\
\text { Estimate }\end{array}$ \\
\hline $\mathrm{H}_{1 \mathrm{a}}:$ Sentiment towards Advertising $\rightarrow$ Materialism & $.144(.057)$ & $1.995^{*}$ & .046 & .165 \\
\hline $\mathrm{H}_{2 \mathrm{a}}:$ Materialism $\rightarrow$ Vanity (Concern for Phy. Appearance) & $1.387(.196)$ & $7.063^{*}$ & .000 & .838 \\
\hline $\mathrm{H}_{2 \mathrm{~b}}:$ Materialism $\rightarrow$ Vanity (View of Phy. Appearance) & $1.040(.158)$ & $6.565^{*}$ & .000 & .795 \\
\hline $\mathrm{H}_{2 \mathrm{c}}:$ Materialism $\rightarrow$ Vanity (Concern for Achievement) & $1.256(.187)$ & $6.732^{*}$ & .000 & .809 \\
\hline $\mathrm{H}_{2 \mathrm{~d}}$ : Materialism $\rightarrow$ Vanity (View of Achievement) & $.710(.117)$ & $6.050^{*}$ & .000 & .669 \\
\hline $\mathrm{H}_{3 \mathrm{a}}$ : Sentiment towards Advertising $\rightarrow$ Vanity (Concern for Phy. Appearance) & $.005(.074)$ & .072 & .943 & .005 \\
\hline $\mathrm{H}_{3 \mathrm{~b}}$ : Sentiment towards Advertising $\rightarrow$ Vanity (View of Phy. Appearance) & $-.017(.057)$ & -.288 & .773 & -.018 \\
\hline $\mathrm{H}_{3 \mathrm{c}}$ : Sentiment towards Advertising $\rightarrow$ Vanity (Concern for Achievement) & $-.012(.071)$ & -.166 & .868 & -.011 \\
\hline $\mathrm{H}_{3 \mathrm{~d}}:$ Sentiment towards Advertising $\rightarrow$ Vanity (View of Achievement) & $.014(.047)$ & .298 & .766 & .019 \\
\hline
\end{tabular}

$\begin{array}{cr}\text { Overall Fit Measures } & \\ \chi^{2}(\mathrm{df}) & \mathbf{8 5 4 . 7 2 5}(\mathbf{3 9 2}) \\ \text { GFI } & .972^{\mathbf{a}} \\ \text { CFI } & .985^{\mathbf{a}} \\ \text { NFI } & \mathbf{. 9 7 3}^{\mathbf{b}} \\ \text { RFI } & \mathbf{. 6 8}^{\mathbf{b}} \\ \text { RMSEA } & \mathbf{. 0 5 7}^{\mathbf{c}}\end{array}$

\footnotetext{
${ }^{*}$ Statistically significant at the 0.05 level

${ }^{a}$ Desirable fit indices value: $>.90$

${ }^{\mathrm{b}}$ Desirable fit indices value: $>.95$

${ }^{\mathrm{c}}$ Acceptable values range from .05 and .08
} 